\title{
Efficiency of a Woody 60 processor attached to a Mounty 4100 tower yarder when processing conifer- ous timber from thinning operations
}

\author{
S.A. Borz, M. Bîrda, Gh. Ignea, B. Popa, V.R. Câmpu, E. Iordache, R.Al. Derczeni
}

Borz S., Bîrda M., Ignea Gh., Popa B., Câmpu V.R., Iordache E., Derczeni R.Al., 2014. Efficiency of a Woody 60 processor attached to a Mounty 4100 tower yarder when processing coniferous timber from thinning operations . Ann. For. Res. 57(2): 333-345, 2014.

Abstract. Processor tower yarders (PTY) represent the current state of yarding technology being extensively used in mountainous conditions such as those from Central Europe where they were also developed and used for the first time. In proper technical conditions which are mostly related to forest road infrastructure such equipment may be introduced by technology transfer in other countries such as Romania where they could replace actual less-efficient forest equipment used in steep terrains. The aim of this study was to evaluate the efficiency of such equipment in conditions of thinning operations by adapting a time study to the general concepts and by using data collection techniques to suit the operational conditions imposed by such equipment. In conditions of a mean tree volume of $0.21 \mathrm{~m}^{3}$ $\times$ tree $^{-1}$, the results of our study indicate net production rates as high as $12.72 \mathrm{~m}^{3} \times \mathrm{h}^{-1}$ when processing trees on landing, which could be also improved up to $17.52 \mathrm{~m}^{3} \times \mathrm{h}^{-1}$ if the PTY have been be adequately installed on the forest road. Another key aspect which could improve the efficiency of such equipment performing landing operations is the number of planned and realized wood assortments since the time expenditure was affected by their number. Given the reduced impact on forest soils as well as the increased efficiency of tower yarders, our study concludes that there would be a lot of potential in actually using them in the Romanian forests located in steep terrain, if proper transportation infrastructure would exist. Keywords efficiency, time expenditure, productivity, processor tower yarder, landing operations, traditional harvesting equipment

Authors. Stelian Alexandru Borz (stelian.borz@unitbv.ro), Marcian Bîrda, Gheorghe Ignea, Bogdan Popa, Vasile Răzvan Câmpu, Eugen Iordache, Rudolf Alexandru Derczeni - Transilvania University of Braşov, Dept. of Forest Engineering, Forest Management Planning and Terrestrial Measurements, Şirul Beethoven - 1, Braşov - 500 123, Romania.

Manuscript received July 05, 2014; revised October 01, 2014; accepted October 10, 2014; online first October 15, 2014. 


\section{Introduction}

Specific to forest vegetation distribution in Romania is that most of the forests are located in mountainous regions, where Norway spruce (Picea abies Lam.) covers about 1.43 million hectares distributed on about $22 \%$ of the national forest covered area (Şofletea \& Curtu 2008). Also, within a production cycle, in such forests are to be expected several thinning operations (Nicolescu 2014). On the other hand, the first and second extractions in thinning operations performed in Romania are usually done by associations of low-mechanization equipment such as chainsaws and animal traction (Borz \& Ciobanu 2013, Oprea 2008, Sbera 2007), generally yielding small production rates. While it is generally accepted that the efficiency of harvesting operations is strongly correlated with the mechanization level (Oprea 2008, Ciubotaru 1998), the latter depends in a great measure by a series of factors such as the forest type, species, the used management methods, terrain configuration and climatic conditions (Vusić et al. 2013), as well as by the level of social acceptance and forest related law in different regions. Usually, this leads to certain options in what concerns the use of different forest equipment, mainly based on an economic analysis (Oprea \& Borz 2007). Cable yarders are forest equipment primary used as non-ground based wood extraction means (Oprea 2008), being characterized by a long tradition in use, especially in the Central European countries (Heinimann et al. 2001). From these, sledge yarders (SY), also known as conventional or classic yarders (Matsuno and Koike 2012, Oprea 2008) have became a well-known forest technology since the $1960 \mathrm{~s}$, while the first tower yarders (TY) have been designed and used starting with the 1970s, gradually replacing the former ones (Heinimann et al. 2001). Such wood extraction means may be equipped with a wood processor mounted on a hydraulic crane, these constructive variants being known as proces- sor tower yarders (PTY) and representing the state-of-art in yarding technology since the 1990s (Heinimann et al. 2001). In this context, a massive technology transfer was expected to countries having forest located in mountainous areas even if this kind of technology was less known at its appearing time (Heinimann et al. 2001). However, being conditioned by a highly developed forest accessibility (Oprea 2008), and maybe due to the increased operational costs (Ghaffariyan et al. 2010) the technology transfer has been slower, even in the case of developed countries (Matsuno \& Koike 2012). While there is a strong drawback in what concerns the use of cable yarders in Romania (Oprea 2008, Sbera 2007), TY and PTY technologies started lately to gain a relative significance in what concerns their use (Borz et al. 2011). On the other hand, when dealing with scientific studies addressing this kind of equipment, the situation is quite different since a lot of attention has been given by scholars to SY, TY and PTY forest equipment. In such scientific studies, the optimization of energy expenditure derived from fossil fuels still needs a lot of attention as pointed out by Cavalli (2012). At the same the same time, the direct fossil energy input regarded as fuel and lubricants consumption depends in a great measure on the level of mechanization as well as on the work organization respectively the succession of certain work elements requiring different amounts of energy within a given operation. Usually, when using a PTY technology, trees are felled using a chainsaw, yarded and processed at the roadside or landing in the so-called full tree (FT) harvesting system. At the roadside, processing operations consist of tree delimbing, bucking, sorting and stacking of produced wood assortments (Borz et al. 2011, Ghaffariyan et al. 2009). While the roadside processing in case of such equipment does not affect the overall system's productivity (Ghaffariyan et al. 2010), it may become significant in the total fossil energy input since all the work elements performed here are mechanized. Yet, the avail- 
able information concerning the factors which affect the time and energy inputs generated by roadside processing using PTY technology is still limited, although the time consumed in such operations may be as high as $35-45 \%$ of the total yarding system time (Messingerová et al. 2009). Furthermore, the traditional tree delimbing, bucking and stacking operations at the roadside which are performed using chainsaws and other non-mechanized stacking means are well-known as great time and energy consumers, especially in the case of small trees such as those harvested in thinning operations (Oprea 2008, Ministerul Industrializării Lemnului şi Materialelor de Construcții 1989), while the use of a technology integrating a single equipment able to perform all the mentioned operations may yield substantial time and energy savings. On the other hand, it became a tradition to use work measurement studies in harvesting operations when one tries to estimate the efficiency of a given system or equipment (Magagnotti \& Spinelli 2012). Such studies are performed in order to evaluate the efficiency of new, unused equipment or to test given equipment in new unstudied conditions, usually yielding empirical models having either a predictive or estimative purpose (Visser $\&$ Spinelli 2012) which are very useful in the forest related applied science. Also, according to their specific goals and experimental setup, work measurement studies may have either an observational or experimental character (Magagnotti \& Spinelli 2012). When dealing with given work elements (Björheden et al. 1995) which are overlapping in a great proportion within a work cycle, such as in the case of using processors, it is recommended to define a higher level work element which to include those elements which are overlapped (Magagnotti \& Spinelli 2012), procedure which supposes the implementation of allocation rules, or to split a given work cycle in as many elements as strictly necessary for achieving the purpose of a study since the observer-induced variability has an effect in case of very short work elements (Spinelli et al. 2013). However, an approach at the elemental time level may generate other important advantages when one tries to get a deepened overview on those work elements which may be improved, excluded or reengineered within a work cycle in order to increase the overall efficiency (Magagnotti \& Spinelli 2012).

In this context, the main aim of this study was to identify the factors and at what extent they may affect the time consumption in landing processing operations when using a Woody 60 processor mounted on a Mounty 4100 PTY. Additionally, the results of this study are compared against the performances which may be yielded when using traditional equipments for landing operations in Romania for the same operational conditions. Along with the predictive and/or estimative capacity, the results of this study may be useful in operational planning, energetic analysis, LCA studies and operational costing of harvesting operations.

\section{Material and methods}

\section{Study location}

The data needed for this study was collected in August of 2011 when thinning operations were performed in two Norway spruce stands (compartments A and B) located on the slopes of Leaota Mountains, near the border of Argeş and Dâmbovița counties, Romania. The time study data was collected for a number of 7 working days, during which a total volume of $36.92 \mathrm{~m}^{3}$ was processed, of which approximately $70 \%$ was processed in compartment $\mathrm{A}$. The relevant descriptive characteristics of harvested stands are given in table 1.

\section{Work organization and equipment descrip- tion}

Similar to other studies performed on PTY technology (Ghaffariyan et al. 2009), during 
this study trees were motor-manually felled and extracted as full trees at the landing. Here, the trees were delimbed, bucked and stacked by a Woody 60 processor (Figure 1). The work team which performed all the operations consisted of one faller, one choker-setter and one processor operator. Faller performed only the tree felling, choker-setter was responsible by lateral yarding which was performed by the means of a Liftliner 4000 carriage unit equipped with an IVECO self-propelling engine, while the processor operator was in charge of hauling and landing operations. Processor's operator had a work experience of one year at the moment of data collection. During the field observations all the timber was yarded uphill. A basic description of the standard technical description of the used PTY is given in Table 2. Also, during the field study, four round wood assortments were produced at 1.5, 2.0, 3.0 and
4.0 meters in length.

\section{Field data collection}

In order to collect the necessary data we designed and adapted a time study to the general concepts described by Björheden et al. (1995) respectively Magagnotti \& Spinelli (2012). Given the fact that, in case of using fully mechanized equipments such as tree processors, landing operations are performed at considerably increased speeds, in order to eliminate the issues related to work elements delimitation and to increase the accuracy of data yielded by the study, we used a video camera for collecting the necessary time data. Thus, for each load detached at the landing a media file was recorded and saved on the internal memory during the field sampling study. Therefore, the work and time elements were

Table 1 Basic description of harvested stands

\begin{tabular}{lllllll}
\hline Compartment & $\begin{array}{l}\text { Area } \\
{[\mathrm{ha}]}\end{array}$ & Tree composition & $\begin{array}{l}\text { Age } \\
{[\text { years }]}\end{array}$ & $\begin{array}{l}\text { Mean DBH } \\
{[\mathrm{cm}]}\end{array}$ & $\begin{array}{l}\text { Mean Height } \\
{[\mathrm{m}]}\end{array}$ & $\begin{array}{l}\text { Mean tree volume } \\
{\left[\mathrm{m}^{3}\right]}\end{array}$ \\
\hline $\mathrm{A}$ & 15.4 & $100 \%$ Spruce & 50 & 21 & 20 & 0.224 \\
$\mathrm{~B}$ & 13.5 & $100 \%$ Spruce & 50 & 15 & 17 & 0.128 \\
\hline
\end{tabular}

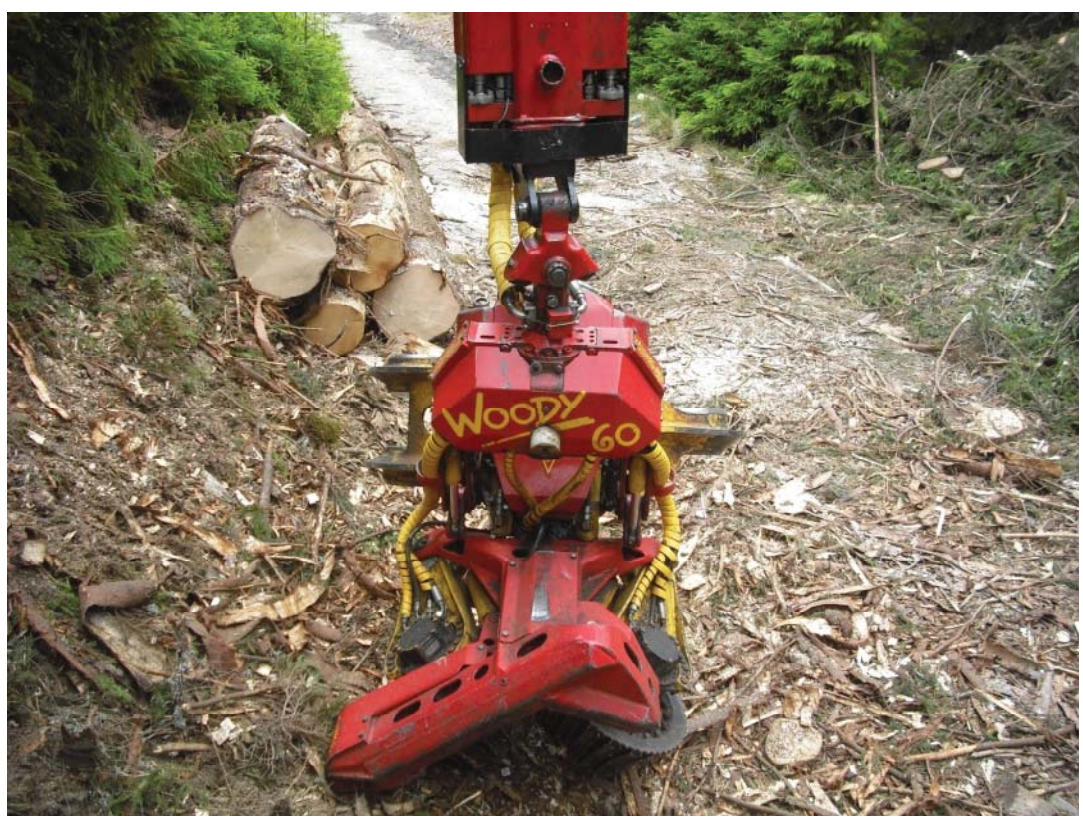

Figure 1 Woody 60 processor used in operations at the studied site 
delimited respectively timed at the office by replaying each recorded media file collected in the field. A description of each work (time) element is given in Table 3 .

Additionally, a filed book was designed and used in order to collect values of operational variables. Thus, for each processed tree were measured and collected the breast height diameter $(D B H)$ and height $(H)$. When dealing with broken trees, tree parts or logs which were processed at the felling site (only few cases), diameters at the small end (SED), large end

Table 2 Technical description of Mounty 4100 PTY

\begin{tabular}{ll}
\hline Truck & MAN TGA 33430 \\
\hline Tower & $13.1 \mathrm{~m}$, swinging tower \\
\hline Carriage & Liftliner 4000 \\
\hline Processor & Woody 60 \\
\hline Maximum felling diameter $[\mathrm{cm}]$ & $60(75)$ \\
Delimbing diameter $[\mathrm{cm}]$ & $8-60$ \\
Maximum grapple opening $[\mathrm{cm}]$ & 125 \\
Forward feed power $[\mathrm{kN}]$ & $36-45$ \\
Forward feed speed $\left[\mathrm{m} \times \mathrm{s}^{-1}\right]$ & $0-5$ \\
Chainsaw speed $\left[{\left.\mathrm{m} \times \mathrm{s}^{-1}\right]}_{\text {Control system }}\right.$ & 40 \\
\hline
\end{tabular}

Table 3 Description of work (time) elements specific to landing processing operations in this study

\begin{tabular}{|c|c|c|c|}
\hline \multirow{2}{*}{$\begin{array}{l}\text { Name and abbreviations of the work } \\
\text { (time) elements }\end{array}$} & \multicolumn{2}{|c|}{ Abbreviations } & \multirow[b]{2}{*}{ Observations specific to this study } \\
\hline & $\begin{array}{l}\text { Work } \\
\text { element }\end{array}$ & $\begin{array}{l}\text { Time } \\
\text { element }\end{array}$ & \\
\hline $\begin{array}{l}\text { Boom movement from the rest place } \\
\text { to first tree to be processed and back } \\
\text { to the rest place after tree processing }\end{array}$ & $B M_{w e}$ & $B M_{t}$ & - \\
\hline Workplace clearing of branches & $C_{w e}$ & $C_{t}$ & $\begin{array}{l}\text { Performed before or during a processing work } \\
\text { cycle }\end{array}$ \\
\hline Tree securing in the processor & $T S_{w e}$ & $T S_{t}$ & Performed each time a tree was processed \\
\hline Tree delimbing & $T D_{w e}$ & $T D_{t}$ & $\begin{array}{l}\text { Performed in most of cases. Required in most } \\
\text { of the cases several processor movements on } \\
\text { the tree }\end{array}$ \\
\hline Tree bucking & $T B_{w e}$ & $T B_{t}$ & $\begin{array}{l}\text { Effective crosscutting (including topping) } \\
\text { and time consumption for decision making. } \\
\text { Performed either over a wood stack or a } \\
\text { branches pile }\end{array}$ \\
\hline $\begin{array}{l}\text { Boom movement between } \\
\text { assortment stacks and/or branches } \\
\text { pile }\end{array}$ & $B S P_{w e}$ & $B S P_{t}$ & ( \\
\hline Personal delay & - & $P D_{t}$ & \\
\hline Operational delay & - & $O P_{t}$ & $\begin{array}{l}\text { Solving issues such as: processor relocation } \\
\text { on the tree in order to avoid big branches, } \\
\text { chainsaw use in removing big branches, tree } \\
\text { curvature or forking }\end{array}$ \\
\hline Processing work cycle & $P_{w e}$ & $P_{T}$ & $\begin{array}{l}\text { Sum of work and time elements needed for full } \\
\text { processing of one tree, excluding delays }\end{array}$ \\
\hline
\end{tabular}


$(B E D)$ and lengths $(L)$ were collected as well. The above described procedure was applied for a total number of 135 processed trees. Other operational variables were either calculated (tree volume $-V$ ) or measured based on the replayed media files (number of the performed crosscuts on each tree $-N C)$. Tree volume $(V)$ was estimated based on tree height $(T H)$ and breast diameter $(D B H)$ using the procedures described by Giurgiu et al. (2004). All the data (operational variables and time elements) was centralized in a MS Excel sheet which served as a primary database for further data analysis. Due to the fact that the operator's behavior may be affected when he/she is the subject of observation, we performed the necessary steps in order to avoid the data variability which otherwise may be generated by this aspect. Therefore, we used the general recommendations when conducting such studies, by asking the operator to work as usual and by communicating him the intended purpose of the study. This way, data was collected in the field phase by a team of three researchers, one being responsible of recording video files, while the other two performed measurements on the processed trees.

\section{Data analysis}

Time study data was analyzed using the general concepts currently used in observational modeling studies (Magagnotti \& Spinelli 2012). Therefore, we assumed that a full processing work cycle time was the sum of all the time consumption elements excluding delays, and its variation may be explained by the variation of all the measured or calculated process variables: number of crosscuts $(N C)$, tree height $(T H)$, breast diameter $(\mathrm{DBH})$ and tree volume $(V)$. Since generating descriptive statistics which to describe best the experimental conditions represents an important step in work measurement studies (Spinelli \& Magagnotti 2012), a first procedure in statistical analysis consisted of a normality check which was con- ducted for each analyzed variable in order to choose the most reliable descriptive statistics (Zar 1974). In order to detect possible linear relations between the independent variables we performed a correlation analysis using a correlation matrix. This way we have identified strong correlations between the analyzed independent variables and we used a threshold set at $R^{2}=0.6$ in order to exclude breast diameter $(D B H)$ and tree height $(T H)$, based also on logical reasons due to the existence of deterministic mathematical relations between $D B H$, $T H$ and $V$. Next step included the development of linear regression models for estimating the time consumed within a full processing work cycle $\left(P_{T}\right)$ as a function of the remaining process variables $(N C$ and $V$ ). For this purpose we analyzed all the remaining possible linear models, by setting an exclusion threshold of $p$ $\leq 0.01$ for each independent variable, meaning that we assumed a risk of up to $1 \%$ that a given independent variable would not be significant for the developed model. The same procedure was used when trying to accommodate the global significance of a given model. The share of each time element within a processing work cycle was calculated by considering its proportion within the total delay free recorded time. Net $(N P R)$ and gross $(G P R)$ production rates for the studied conditions were calculated by considering the quantity of wood as input in the process and the total time recorded without and with delays respectively. Comparisons between traditional and PTY time expenditures were made based on the results concerning the time consumption yielded by this study and those described in the national standards (Ministerul Industrializării Lemnului şi Materialelor de Construcții 1989) in order to emphasize the eventual differences between the used equipments.

\section{Results}

The normality check performed on all the vari- 
ables taken into study indicated that none of them actually followed a normal distribution. Given the results we have chosen the median as a descriptive statistic instead of the mean values. In order to process the 135 trees taken into study, an exact number of 500 crosscuts (Table 4) were required, including the cuts performed in order to top the trees or that performed once or several times in order to get a planar section at the base of the trees. Within a delayfree work cycle, the highest time consumption was recorded in case of loaded boom movement between assortment stacks including its movements to the braches pile in order to top the trees (Table 4) which accounted for almost $31 \%$ (Figure 2), emphasizing that sorting operations are great time consumers when using this kind of equipment in the given conditions (Table 4). Also, tree securing in the processor was responsible by the lowest amount of time (Table 4), accounting for about $3 \%$ of the total processing time expenditure (Figure 2). Within a delay-free work cycle time, important amounts of time were required by work place clearing, delimbing and bucking (Table 4), while work place clearing presented the second important time expenditure, being responsible for about $27 \%$ of the total delay-free processing time (Figure 2). Also, in the studied conditions (Table 4, Figure 2), tree delimbing took less time (11\%) than tree bucking (24\%). The linear regression models developed in order to estimate the delay-free work cycle time expenditure (Table 5) included as independent variables tree volume $(V)$ and number of crosscuts $(N C)$ performed on each tree. Regression models were developed for two alternative groups of variants (Table 5). The first group of variants was developed in order to estimate the delay-free time expenditure $\left(P_{T}\right)$ as a function of tree volume $(V)$, number of crosscuts $(N C)$ respectively the tree volume $(V)$ and the number of crosscuts $(N C)$ considered together. The second group of variants was developed in order to estimate the delay-free time expenditure $\left(P_{T}^{*}\right)$ as a function of the same independent variables, by excluding the time expenditure involved by workplace clearing because in certain operational conditions, related mostly to the yarder's setup, this work element would not be required. The second group of variants actually succeeded to improve the determination coefficient by an increment of $16-25 \%$ in what concerns the proportion in which the used independent variables explained the variation of a delay-free work cycle time expenditure.

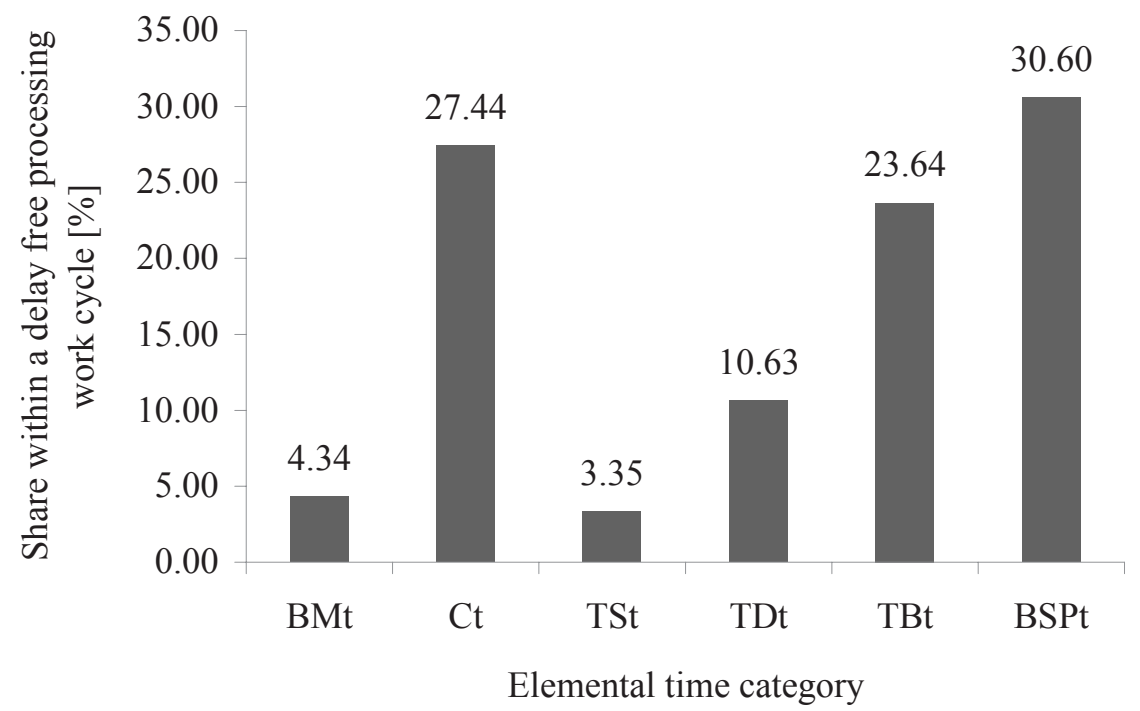

Figure 2 Shares of elemental time categories within a delay-free work cycle time 
Table 4 Descriptive statistics of operational conditions and time consumption categories

\begin{tabular}{|c|c|c|c|c|c|}
\hline Parameter & Total & Minimum & Maximum & Median & $\begin{array}{l}\text { Standard } \\
\text { deviation }\end{array}$ \\
\hline \multicolumn{6}{|l|}{ Operational variables } \\
\hline No. of processed trees $-N T$ & 135 & - & - & - & - \\
\hline Diameter at the breast height $-D B H(\mathrm{~cm})$ & - & 10.00 & 42.000 & 20.000 & \pm 6.870 \\
\hline Tree height $-T H(\mathrm{~m})$ & - & 4.00 & 25.000 & 14.000 & \pm 4.750 \\
\hline Tree volume $-V\left(\mathrm{~m}^{3}\right)$ & 36.92 & 0.02 & 1.206 & 0.208 & \pm 0.224 \\
\hline No. of crosscuts $-N C$ & 500 & 1 & 9 & 4 & \pm 1.490 \\
\hline \multicolumn{6}{|l|}{ Time consumption } \\
\hline$B M_{t}$ (seconds) & 453.1 & 0.81 & 15.00 & 3.00 & \pm 2.36 \\
\hline$C_{t}($ seconds $)$ & 2867.9 & 0.00 & 135.25 & 15.17 & \pm 22.86 \\
\hline$T S_{t}$ (seconds) & 350.6 & 1.00 & 15.67 & 2.00 & \pm 1.84 \\
\hline$T D_{t}$ (seconds) & 1111.1 & 0.00 & 52.37 & 6.00 & \pm 8.27 \\
\hline$T B_{t}$ (seconds) & 2470.6 & 4.00 & 50.00 & 17.00 & \pm 8.24 \\
\hline$B S P_{t}($ seconds $)$ & 3198.7 & 6.50 & 96.00 & 21.00 & \pm 13.18 \\
\hline$P_{T}($ seconds $)$ & 10452.0 & 26.00 & 288.50 & 70.38 & \pm 38.16 \\
\hline$P D_{t}$ (seconds) & 343.3 & - & - & - & - \\
\hline$O P_{t}$ (seconds) & 387.4 & - & - & - & - \\
\hline
\end{tabular}

Table 5 Regression models for time consumption estimation

\begin{tabular}{|c|c|c|c|c|c|}
\hline \multirow{2}{*}{ Time consumption model } & \multirow{2}{*}{$R^{2}$} & \multirow{2}{*}{$N$} & \multirow{2}{*}{ Constant } & \multicolumn{2}{|c|}{ Coefficients ( $p$ - values) } \\
\hline & & & & $V\left(\mathrm{~m}^{3}\right)$ & $N C$ \\
\hline Delay-free processing work cycle time $-P_{T}$ (seconds) & 0.39 & 135 & 25.59 & $\begin{array}{l}46.62 \\
(p=0.003)\end{array}$ & $\begin{array}{l}10.48 \\
(p<0.000)\end{array}$ \\
\hline Delay-free processing work cycle time $-P_{T}$ (seconds) & 0.35 & 135 & 20.97 & - & $\begin{array}{l}15.17 \\
(p<0.000)\end{array}$ \\
\hline Delay-free processing work cycle time $-P_{T}$ (seconds) & 0.30 & 135 & 51.75 & $\begin{array}{l}92.84 \\
(p<0.000)\end{array}$ & - \\
\hline $\begin{array}{l}\text { Delay-free processing work cycle time excluding } \\
\text { workplace clearing }-P_{T}^{*} \text { (seconds) }\end{array}$ & 0.48 & 135 & 21.95 & $\begin{array}{l}26.42 \\
(p=0.002)\end{array}$ & $\begin{array}{l}7.29 \\
(p<0.000)\end{array}$ \\
\hline $\begin{array}{l}\text { Delay-free processing work cycle time excluding } \\
\text { workplace clearing }-P_{T}^{*} \text { (seconds) }\end{array}$ & 0.44 & 135 & 19.33 & - & $\begin{array}{l}9.95 \\
(p<0.000)\end{array}$ \\
\hline $\begin{array}{l}\text { Delay-free processing work cycle time excluding } \\
\text { workplace clearing }-P_{T}^{*} \text { (seconds) }\end{array}$ & 0.35 & 135 & 40.16 & $\begin{array}{l}58.59 \\
(p<0.000)\end{array}$ & - \\
\hline
\end{tabular}

However, it seemed that taken apart, tree volume had less influence on the time consumption variation (Table 5). No matter the developed model, all the independent variables were very significant $(p<0.01)$ in explaining the time consumption. This was also true in case of global significance tests $(p<0.000)$. While the number of crosscuts (NC) explained the variation of time consumption for tree bucking work element in a proportion of about $67 \%$
(Figure 3), the attempt made in order to express the time consumption for tree delimbing $\left(T D_{t}\right)$ as a function of tree height $(T H)$ did not yield satisfactory results because the latter explained the time variation only in a proportion of $9 \%$ (Figure 4). The detailed analysis of processing time yielded a number of 2.903 effective work hours and a number of 3.106 hours including delays (Table 6). In these conditions and for a total processed volume of $36.92 \mathrm{~m}^{3}$, the net 


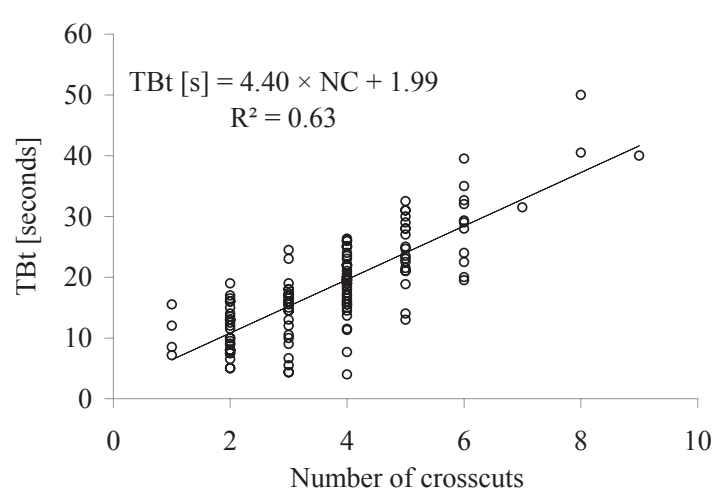

Figure 3 Variation of tree bucking time $\left(T B_{t}\right)$ as a function of number of crosscuts $(N C)$

$(N P R)$ and gross $(G P R)$ production rates of $12.72 \mathrm{~m}^{3} \times \mathrm{h}^{-1}$ and $11.89 \mathrm{~m}^{3} \times \mathrm{h}^{-1}$ respectively were achieved (Table 6). Particularly interesting would be the results obtained after the exclusion of workplace clearing time, as this may be accommodated in other real world scenarios, because in such conditions one may obtain an increment of about $38 \%$ of the production rate (Table 6).

In what concerns the entire process efficiency expressed as the time required for processing and stacking one cubic meter of wood, it seems that PTY technology is far superior if compared with traditional setups in almost equal (similar) working conditions. For instance, in order to fully process and stack one cubic meter of wood in this study were required about 0.08 hours (Table 7) result which seems to indicate that a PTY technology is almost 13 times more productive than a traditional system used in landing operations. The comparisons made in Table 7 use the data procured from this study against the data provided by national standards (Ministerul Industrializării Lemnului şi Materialelor de Construcții 1989).

\section{Discussion}

One major advantage when using PTYs resides in the fact that this kind of equipments actually may deliver tree branches in accessible places (roadside) where further chipping operations

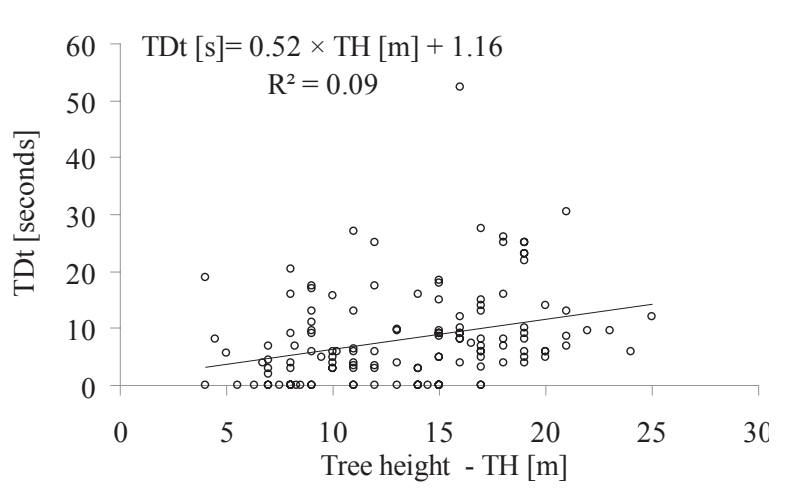

Figure 4 Variation of tree delimbing time $\left(T D_{t}\right)$ as a function of tree height $(T H)$

may be performed in order to produce wood chips for energetic purposes. This would be a significant advantage when considering the importance of using such wood for energetic purposes, but one should consider also the national laws regarding the allowed harvesting methods. However, in order to make available also the tree branches, adequate setups of the main machine on the forest roads is in question since in the case of forest roads developed on the slopes the available space is quite limited. On the other hand, when one does not consider the further use of tree branches as a potential energy source, is more advantageous to actually locate the machine near the fill slope of the road in order to avoid supplementary time expenditures involved by work place clearing, a fact which may significantly enhance the efficiency of landing processing operations. Natural tree pruning as other factors such as forking or curvature play key roles when using such equipments and may affect also the system's efficiency when extraction distances are very short and the extraction intensity is greater, fact which may be compensated as the harvesting operations advance on a given yarding corridor. Also, when the branches piles are located on the forest road, further problems are generated by their dimensions and additional time expenditures are involved by their accommodation. Tree processing when dealing with small diameter trees having also great heights may generate other problems such as 
Table 6 Estimates on net and gross production rates

\begin{tabular}{|c|c|c|c|}
\hline Time consumption category & $\begin{array}{l}\text { Total } \\
\text { processed } \\
\text { wood } \\
\left(\mathrm{m}^{3}\right)\end{array}$ & $\begin{array}{l}\text { Net } \\
\text { production } \\
\text { rate } \\
\left(\mathrm{m}^{3} \times \mathrm{h}^{-1}\right)\end{array}$ & $\begin{array}{l}\text { Gross } \\
\text { production } \\
\text { rate } \\
\left(\mathrm{m}^{3} \times \mathrm{h}^{-1}\right)\end{array}$ \\
\hline Delay-free total processing time (hours) $-T T=2.90$ & 36.92 & 12.72 & - \\
\hline $\begin{array}{l}\text { Delay-free total processing time, excluding workplace clearing } \\
\text { (hours) }-T T^{*}=2.11\end{array}$ & 36.92 & $17.52 *$ & - \\
\hline Total processing time including delays (hours) $-T T D=3.11$ & 36.92 & - & 11.89 \\
\hline
\end{tabular}

Table 7 Efficiency of traditional equipments versus PTY in landing operations

Landing operations system description

Efficiency

$\left(\mathrm{h} \times \mathrm{m}^{-3}\right)$

This study: delimbing, crosscutting, sorting and stacking using the same equipment

(excluding workplace clearing)

0.06

This study: delimbing, crosscutting, sorting and stacking using the same equipment (including workplace clearing)

0.08

Traditional system: motor-manual delimbing and bucking, log moving using tractors and manual stacking

an increment of tree breakage rate during delimbing operations, reason for which, in this study the operator proceeded in many cases to partial delimbing followed by crosscutting. However, this approach, as well as the fact that after a partial processing of each log, several movements were required between branches pile and wood stacks, led to a important time expenditure. Furthermore, in the given operational conditions, the time expenditure was also affected by the number of produced wood assortments. If compared against the results reported by other studies such as that performed by Messingerová et al. (2009) several points may be addressed. On the one hand, when analyzing the total delay-free expenditure involved by tree processing at the road side, our study suggests that for a full processing of a tree were required about 70 seconds $(1.17 \mathrm{~min}$ utes) in the given operational conditions and, depending on the number of trees within a load detached at the landing, results similar to those reported by Messingerová et al. (2009) may be obtained. However, in this study, the tree delimbing operations took less time within a full processing work cycle, maybe due to more facile conditions regarding the natural pruning of trees. For instance, when comparing the time expenditure for tree delimbing with the results obtained in the aforementioned study, we found out that in our study this operation took about $11 \%$ of the total time, being significantly smaller. These results are somehow different when compared with the use of such processors for complete harvesting, including tree felling (Oprea 2008), or for the same kind of operations (Messingerová et al. 2009).

Tree crosscutting took in our study about $24 \%$ of the total delay-free time expenditure and it did not came as a surprise since we included in this category also the time expenditure due to decision making when crosscutting, time spent for several crosscuts performed in order to get a planar section at the tree base or to remove rotten parts, as well as all the time expenditure involved by tree topping. On the other hand, effective processing time as defined by Dvořák (2010) may account for $17-93 \%$ of the total 
time when using mechanical processing equipments, while the results of our study according to the described definition suggested a share of about $68 \%$. As a general fact, even if not documented herein, when using the main saw, time consumption was smaller by comparison with that involved by the small saw which was used every time to remove the tree top. Substantial improvements may be obtained in what concerns the processing efficiency in terms of time expenditure and productivity if one considers an adequate setup of machine, removing this way the time expenditure involved by workplace clearing; similar improvements may be obtained by limiting the number of produced assortments. Also, the developed time consumption models were significant at the chosen confidence thresholds even if the total variability of time consumption expenditure was explained only in proportions of $30-48 \%$. Maybe the unexplained variability was induced by factors which could not be properly or were not quantified in the given operational conditions such as the moment of occurrence and the extent of workplace clearing operations, decision making on one given wood assortment and its proper positioning in the right stack, tree pruning as well as the moment and time expenditure involved by stacks rearranging. What is generally true in such studies is the fact that the tree size affects the time expenditure as provided also by other studies even if the explaining capacity of a given model is less when processing trees with such equipments (Stampfer \& Steinmüller 2001, Nurminen et al. 2006, Danilović et al. 2011). On the other hand, the use of such equipments in landing operations may generate high production rates which in our study were as high as $12.72 \mathrm{~m}^{3}$ $\times \mathrm{h}^{-1}$, fact which should be considered when making decisions or developing laws about the type of equipments to be used in such operational conditions since the actual used ones are less efficient. However, one bottleneck which should be addressed in the Romanian forest operations is related to the transportation in- frastructure and forest roads network development since such equipments are technically limited to 500-700 meters and economically feasible on shorter distances. Additional reasons which support the mentioned facts are the results we obtained when we compared the traditional used equipments against the studied one and we found out that the time expenditure when using PTYs on landings may be significantly reduced. This would be of great importance when harvesting spruce stands in similar conditions, especially in case of increased slope terrains where the harvesting options are anyway limited in thinning operations. Nevertheless, one should consider that the yarders as an option in harvesting operations are more appropriate in steep terrains since their environmental impact is reduced by comparison with ground-based equipments (Oprea 2008).

\section{Conclussions}

Our study addressed the performance of landing operations when using the state-of-art PTY technologies. Generally, our results suggest that by using such equipments significant efficiency enhancements may be achieved if compared with traditionally used forest equipments in case of landing operations, as shown by the productivity and time expenditure indicators presented in this study. However, bottlenecks such as the road infrastructure and legislative aspects should be addressed in order to create the proper technical conditions for using such equipments. On the other hand, as in every productive process, improvements may be suggested for a better organization of landing operations when using mechanical processing equipment. Even if the wood assortments as number and dimensional characteristics are imposed by market requirements, if possible, one should consider limiting their number due to increased time expenditure in actually processing them. Also, if the wood recovery from tree branches is not in question, a better positioning 
of the processor on the roadside may eliminate a substantial part of time expenditure leading this way to a better time management in landing operations, therefore to increased productivity. Given the results of this study, as well as the current extension of such forest equipment in Romanian forestry, we conclude that their use would have more benefits than drawbacks, especially in steep terrains and thinning operations where the harvesting options are limited anyway.

\section{Aknowledgements}

We hereby acknowledge the structural founds project PRO-DD (POS-CCE, O.2.2.1., ID 123, SMIS 2637, ctr. No 11/2009) for providing the infrastructure used in this work and the South East Europe Transnational Cooperation Programme, an EU program for financially support of this research within the project "FOROPA - Sustainable Networks for the Energetic Use of Lignocellulosic Biomass in South East Europe". We would like to thank the representatives of S.C. ALSERFOREST S.R.L., Mr. Eng. Albert Şerban and Mr. Eng. Sorin Şolomonean for making this study possible, as well as to Mr. Eng. Alexandru Stanciu, Mr. Eng. Constantin Ticu and Mr. Daniel Ichim for their valuable support and participation in data collection and processing activities.

\section{References}

Björheden R., Apel K., Shiba M., Thompson M., 1995. IUFRO forest work study nomenclature. Grapenberg, Sweden: Swedish University of Agricultural Science, Department of Operational Efficiency, 16 p.

Borz S.A., Ciobanu V.D., 2013. Efficiency of motor-manual felling and horse logging in small-scale firewood production. African Journal of Agricultural Research 8(24): 3126-3135.

Borz S.A., Bîrda M., Ignea G., Oprea I., 2011. Technological aspects regarding timber exploitation using Mounty 4100 cable yarder. Bulletin of Transilvania University of Braşov 4(53): 1-6.

Cavalli R., 2012. Prospects of research on cable logging in forest engineering community. Croatian Journal of Forest Engineering 33(2): 339-356.

Ciubotaru A., 1998. Exploatarea Pădurilor [Forest Harvesting]. Lux Libris Publishing House, Braşov, 351 p.

Danilović M., Tomašević I., Gačić D., 2011. Efficiency of a John Deere 1470D ECOIII harvester in poplar plantations. Croatian Journal of Forest Engineering 32(2): 533-548.

Dvoŕák J., 2010. Operation time consumption of highpowered harvester in salvage felling. EJPAU 13(4): \#12.

Giurgiu V., Decei I., Drăghiciu D., 2004. Metode şi tabele dendrometrice [Auxological Methods and Tables]. Ceres Publishing House, Bucharest, 575 p.

Ghaffariyan M.R., Stampfer K., Sessions J., 2010. Optimal road spacing of cable yarding using a tower yarder in Southern Austria. European Journal of Forest Research 129: 409-416. DOI: 10.1007/s10342-009-0346-7.

Ghaffariyan M.R., Stampfer K., Sessions J., 2009. Production equations for tower yarders in Austria. International Journal of Forest Engineering 20(1): 17-21.

Heinimann H.R., Stampfer K., Loschek J., Caminada L., 2001. Perspectives on Central European Cable Yarding Systems. In: Schiess P., Krogstadt F. (eds.), International Mountain Logging and $11^{\text {th }}$ Pacific Northwest Skyline Symposium, December 10-12 2001, Seattle, WA, USA. College of Forest Resources, University of Washington and International Union of Forestry Research Organizations, pp. 268-279.

Magagnotti N., Spinelli, R. (Eds.), 2012. COST Action FP0902 - Good Practice Guideline for Biomass Production Studies. CNR IVALSA, Florence, Italy, ISBN97888-901660-4-4, 41 p., available at:www.forestenergy. org.

Matsuno A., Koike K., 2012. Tower yarders, not suitable in Japan? Technology transfer is still going on. In: Pentek T., Poršinsky T., Špročić M. (eds.), Proceedings of the $45^{\text {th }}$ International Symposium on Forestry Mechanization "Forest Engineering: Concern, Knowledge and Accountability in Today's Environment", October 8-12, Dubrovnik (Cavtat), Croatia. Foresty Faculty of Zagreb University, pp. 1-9 (available on CD support).

Ministerul Industrializării Lemnului şi a Materialelor de Construcții, 1989. Norme şi normative de muncă unificate în exploatările forestiere, [Ministry of Wood Industrialization and Construction Materials, 1989. Unified Norms and Normative in Timber Harvesting Operations, Bucharest], Bucureşti, 493 p.

Messingerová V., Stanovský M., Ferenčik M., Kováčik P., 2009. Technological Planning in Cableway Terrains in Slovakia. In: Proceedings of $42^{\text {nd }}$ International Symposium on Forestry Mechanization - FORMEC 2009, 21 24 June 2009, Prague, Czech Republic, CULS, Prague, pp. 307-315.

Nicolescu V.N., 2014. Silvicultură. Volumul II: Silvotehnică [Silviculture. Volume II: Silvotechnics]. Aldus Publishing House, Braşov, 289 p.

Nurminen T., Korpunene H., Uusitalo J., 2006. Time 
consumption analysis of the mechanized cut-to-length harvesting system. Silva Fennica 40(2): 335-363. DOI: 10.14214/sf.346.

Oprea I., 2008. Tehnologia exploatării lemnului [Timber Harvesting Technology]. Transilvania University Press, Braşov, $273 \mathrm{p}$.

Oprea I., Borz S.A., 2007. Organizarea şantierelor de exploatare a lemnului [Harvesting Site Organization]. Transilvania University Press, Braşov, 133 p.

Sbera I., 2007. Resursele de lemn şi potențialul pieței din România [Wood Resources and the Market Potential in Romania]. Meridiane Forestiere 2: 3-7.

Spinelli R, Laina-Relaño R, Magagnotti N, Tolosana E, 2013. Determining observer and method effects on the accuracy of elemental time studies in forest operations. Baltic Forestry 19(2): 301-306.

Stampfer K., Steinmüller T., 2001. A new approach to derive a productivity model for the harvester Valmet 911 Snake. In: Schiess P., Krogstadt F. (eds.), International
Mountain Logging and $11^{\text {th }}$ Pacific Northwest Skyline Symposium, December 10-12 2001, Seattle, WA, USA. College of Forest Resources, University of Washington and International Union of Forestry Research Organizations, pp. 254-262.

Şofletea N., Curtu L., 2008. Dendrologie [Dendrology] "Pentru Viaţă" Publishing House, Braşov, 418 p.

Visser R., Spinelli R., 2012. Determining the shape of the productivity function for mechanized felling and felling-processing. Journal of Forest Research 17: 397-402. DOI: $10.1007 / \mathrm{s} 10310-011-0313-2$.

Vusić D., Susjnar M., Marchi E., Spina R., Zecic Z., Picchio R., 2013. Skidding operations in thinning and shelterwood cut of mixed stands - Work productivity, energy inputs and emissions. Ecological Engineering 61: 216-223. DOI: 10.1016/j.ecoleng.2013.09.052

Zar J.H., 1974. Biostatistical analysis. Englewood Cliffs, USA: Prentice Hall Inc, 620 p. 